\title{
$\$$ sciendo
}

\section{Pharmacogenomics: introduction and use in clinical practice}

\author{
HOLLIE SAUNDERS, DANA HARRIS, RĂZVAN M. CHIRILĂ \\ Mayo Clinic, Department of Internal Medicine, Jacksonville, Florida
}

\begin{abstract}
Pharmacogenomics describes the link between the genetic code and variations in drug response or adverse effects. It is rapidly gaining in both interest and accessibility. The knowledge of the gene-drug pairing for a wide range of medications will allow the clinician to select drugs with the best efficacy, appropriate dose and lowest likelihood of serious side effects.

In order to apply this knowledge, practitioners need to be familiar with the basic principles of pharmacodynamics and pharmacokinetics and how these relate to drug response. Once these are understood, so can be the genetic variations that lead to different phenotypes. Our review explains these concepts and uses examples of commonly prescribed medications and their gene pairings. At the present time, the Food and Drug Administration (FDA) guidelines remain sparse in regards to pharmacogenomic testing but, despite this, direct-to-consumer testing is widely available. In this context, we detail how to interpret a pharmacogenomic report, we review the indications for testing, as well as its limitations.

This information is a step ahead towards invidualized medicine, in the hope that tailoring medications and doses to an individual's genetic make-up will predict a safe and effective response.
\end{abstract}

Key words: pharmacogenomics, clinical practice, CYP450.

\section{INTRODUCTION}

Pharmacogenomics is an area rapidly gaining interest with both physicians and patients. Pharmacogenomics describes the principle of variations in the genetic code resulting in differences in drug response [1]. As our knowledge of genetics increases we are moving more towards a time where medicine can be individualized to the patient. By using a person's individual genetics we are provided with information that will allow us to select a medication with the best chance of efficacy, the best dose, and the lowest likelihood of serious side effects. It has long been understood that medications will have variable effects on an individual basis. Advances have meant that we now know the gene-drug pairing for a wide range of medications. With increasing availability and decreasing cost, there is now a trend towards overall genetic testing for most commonly used medications and this is summarized in a clinically usable report. This makes it more accessible for the physician, as well as the patient and pharmacist. In this review we will go over the basic principles of pharmacogenomics, the most commonly tested genes, the drugs they affect, and what this means for the prescribing provider.

\section{PHARMACOKINETICS AND PHARMACODYNAMICS}

Pharmacokinetics describes those factors that influence the concentration of the drug reaching its target. This includes steps such as absorption, metabolism, distribution, and elimination. Pharmacodynamics are those factors that influence response at, or downstream of the drug target. This includes receptor proteins, membrane channels, and intracellular enzymes. At each step of this process there is the opportunity for variety. Different genetic sequences will encode different proteins, with both the gene and the protein that it encodes often sharing a name. It is the expression of this gene into a trait or characteristic that will determine a person's phenotype. When this is applied to a drug, we are able to understand further how a person may react. Previously this was explored through trial and error; we are now armed with information to allow us suitable drug selection, dose, and monitoring. Below we will address some common genes and proteins implicated in drug response and the effects of their genetic variability.

\section{INDICATION}

At present the recommendations to obtain pharmacogenomic testing are scarce. Most often testing will be obtained by a medical subspecialty for individual drugs. Currently the drugs that have a Food and Drug Administration (FDA) recommendation of gene testing prior to initiation are abacavir and, in individuals of Asian descent, carbamazepine and oxcarbazepine. Both of these are due to the severe 
adverse effects that can occur [2]. Many other drugs have FDA or Clinical Pharmacogenetics Implementation Consortium (CIPC) recommendations for altered dosing based on an individual's genetic testing, but obtaining the testing itself is not required. Therefore, outside of the medications above, testing is down to provider discretion. Some examples of current use in practice include obtaining testing to help guide post-operative pain management, oncologic drugs, or to help with anti-depressant medication selection. Patients are also able to obtain testing themselves with direct-to-consumer tests. These can provide useful information but have drawbacks, as will be discussed below.

\section{CYP450}

A widely known, and important class of genes that are involved in pharmacokinetics are the cytochrome P450 (CYP). The CYP450 genes encode a group of enzymes involved in drug metabolism. The most widely studied CYP450 enzyme is CYP2D6. This enzyme is responsible for the metabolism of a wide variety of drugs such as codeine, metoprolol, fluoxetine, paroxetine, and tamoxifen [3]. CYP2D6 offers an excellent example of how medications may be tailored. Using nortriptyline as an example, individuals who are identified as slow metabolizers based on their CYP2D6 activity will be prone to drug accumulation due to poor metabolism of the drug. This will lead to an increased risk of side effects. In these individuals, lower doses of the medication are still effective while being safe. Fast metabolizers will quickly clear the drug and so receive little therapeutic benefit. These individuals will often require higher doses to achieve the same therapeutic benefit.

In contrast, codeine is a prodrug metabolized by CYP2D6. A prodrug relies on metabolism in order to become its active compound, which in this case is morphine. Individuals who are identified as slow metabolizers will have a poor response to codeine as it will not be metabolized into its active form. Rapid metabolizers, however, will achieve higher than expected levels of morphine, a shorter duration of action, and a high risk of side effects [4].

Another example is Tamoxifen, a selective estrogen receptor modulator (SERM). This medication is used to help prevent the recurrence of estrogenreceptor positive breast cancer. Tamoxifen requires CYP2D6 activity in order to achieve is active metabolites such as endoxifen. Currently tamoxifen reduces recurrence by about $50 \%$ [5] it is possible that this percentage may be altered if an individual's CYP2D6 activity is diminished.

Another important gene is the CYP2C19. The CYP2C19 enzyme is involved in the metabolism of drugs such as clopidogrel, omeprazole and citalopram. Clopidogrel is one of the cornerstones of acute coronary syndrome management (ACS) requiring percutaneous intervention (PCI). At this time all patients receive uniform dosing of this medication, but resistance has been documented with one proposed mechanism of action being through CYP2C19 polymorphims [6]. The consequences of both clopidogrel inefficacy and accumulation can be severe with stent thrombosis and bleeding. Clopidogrel is another example of a pro-drug, requiring metabolism to achieve its active metabolite. Individuals with poor expression of CYP2C19 will be at risk of medication inefficacy due to low levels of active metabolite. These patients can benefit from using another drug such as prasugrel or ticagrelor.

Antidepressants are a commonly used group of medications metabolized by CYP2D6 (fluoxetine, paroxetine as active drugs and venlafaxine as prodrug) and CYP2C19 (citalopram and escitalopram as active drugs). Depression is one of the conditions most frequently treated via trial and error. Often patients will be trialed on one medication with medications being titrated, added, or exchanged until a desired response is achieved. This is resource intensive and difficult for a patient. The Sequenced Treatment Alternatives to Relieve Depression (STAR-D) trial showed that only about $50 \%$ of patients responded to first line therapy, with response being measured as a decrease in symptoms by half. Rates of intolerance to medication were around $16 \%$ with first line therapy, increasing with each line [7]. If, instead, we were able to prescribe medications likely to be effective and with a low chance of side effects it would be of extreme benefit to both patient and physician. Knowing CYP2D6 and CYP2C19 activity will allow us to know which of the anti-depressant medications will be metabolized too quickly to be effective, and which are metabolized too slowly and could result in more adverse effects. The goal is to choose a medication - with the patient - that has the highest chance of being tolerable and effective as a first line.

It is important to note that the CYP 450 enzymes can be also be affected by drug-drug interactions. Widely known is the CYP3A4 enzyme that is induced or inhibited by certain drugs or foods, resulting in the varied metabolism of other drugs. This is not pharmacogenomics and cannot be predicted in genomic reporting. 


\section{TPMT}

Another enzyme involved in metabolism is the thiopurine-S-methyltransferase enzyme (TPMT). This is involved in the metabolism of azathioprine and 6-mercaptopurine. These are immunosuppressive medications used in autoimmune disorders. Low activity of the TPMT enzyme can result in increased levels of the medication metabolites and higher risk of side effects such as treatment-related leukopenia and bone marrow suppression [8]. TPMT polymorphisms provide an example of dose adjustment with genetic variability. Current recommendations are that individuals who are heterozygous for TPMT deficiency should receive a reduced dose by about $50-80 \%$. In those individuals who are homozygous for TPMT deficiency, they should receive a reduced dose of 10-fold and should receive the drug three times weekly instead of daily [9]. When assessing TPMT, genetic testing is preferred to phenotypic testing, because the enzyme level is influenced by numerous factors such as red blood cell transfusion, rapid red blood cell turnover, bone marrow failure or various medications.

\section{HLA}

When it comes to pharmacodynamics the most commonly known drug-gene interactions occur from the human leukocyte antigen (HLA) genes. The HLA genes encode cell surface markers and have been implicated in drug-induced hypersensitivity. The best known examples of this are the association between HLAB15:02 and carbamazepine induced Stevens-Johnson syndrome/toxic epidermal necrolysis, HLAB57:01 and abacavir sensitivity, and HLAB58:01 and allopurinol severe cutaneous adverse reactions. Amongst this group, the Food and Drug Administration (FDA) labelling actually recommends the testing of the associated HLA allele prior to the administration of both abacavir in the general population, as well as carbamazepine and oxcarbazepine in patients of Asian descent [2].

\section{SCLO1B1}

The SCLO1B1 gene encodes a protein that is involved in the hepatic uptake of statin medications. Statin are widely used, not just in treatment, but also commonly prescribed for primary prevention in individuals deemed to have an elevated cardiovascular risk. A variant of this gene can result in reduced transporter activity leading to increased plasma levels and exposure. It is felt that this is one of the mechanisms behind simvastatin induced myopathy, and a significant association has been identified [10].

\section{WARFARIN}

The anti-coagulant medication Warfarin provides an example of how drug pharmacogenomics is not limited to one gene. It also provides an example of the contribution of variation of both pharmacokinetics and pharmacodynamics. Although there are new anticoagulant medications available, their drawbacks mean that warfarin is still a commonly used medication. Warfarin has a narrow therapeutic window with its adverse effects outside of this being thrombosis if sub-therapeutic, and bleeding if supra-therapeutic. This means that dosing of warfarin has long been challenging. The two most commonly associated genes involved in warfarin pharmacogenetics are Vitamin K Epoxide Reductase Complex (VKORC1) and CYP2C9. The VKORC1 gene encodes the warfarin target enzyme. Variants of this gene can increase warfarin sensitivity, increasing the risk of bleeding. CYP2C9 is involved in warfarin metabolism. Some polymorphisms of this gene will result in poor metabolizers, again increasing the risk of bleeding. Access to this information prior to initiation of warfarin may help in shortening the time to achieve a therapeutic level, and may decrease the risk of bleeding [11].

\section{REPORT INTERPRETATION}

Pharmacogenomics testing is offered widely, and as such there will be variation in reporting. In general, the genes tested and their activity will be listed in the report. The drugs are then placed into three categories such as "Use as Directed" or a green category, "Use with caution" or a yellow category, "Use with increased monitoring/consider alternatives" or a red category. Those in the yellow or red categories are drugs that, based on the gene expression, may be prone to accumulation and higher risk of side effects. Due to their large number, reports that are available directly to the consumer are not all regulated or verified. In fact, according to the FDA 
website, the only direct-to-consumer test with marketing authorization is 23 and ME [12]. It is suggested that, if a patient presents with a report that would require medication alteration, it should not be used as a basis to guide decision making until approved testing can be obtained. Once approved testing is obtained, if the prior gene variation is confirmed, then first and foremost the patient should be educated, based on the information above, on what these results mean. Patients with drugs in the yellow or red category should be educated to the fact that this does not mean they are allergic to them. It also does not mean that drugs in this category should be stopped, especially if the alternatives are not appropriate when taking into account the condition they are treating, drug-drug interactions, and cost. Instead, these patients may require dose adjustment or close monitoring for side effects or inefficacy. If the drug in question is one that is usually prescribed by a medical subspecialty, then consulting with that specialist prior to drug alteration is reasonable. The cases where drugs should be completely avoided or stopped are those than can result in life threatening side effects such as Stevens-Johnson syndrome or toxic epidermal necrolysis.

\section{LIMITATIONS}

As important as understanding its role, the limitations of pharmacogenomics also need to be understood. Providers should know that certain factors cannot be taken into account. For example genetic testing does not factor in the presence of co-morbidities, especially of hepatic or renal disease. Both of these organs play an important role in drug metabolism and elimination. Additionally, it does not provide us with information such as allergies to a medication, drug-drug interactions, or drug-food interactions.

There is a large number of steps and variations involved in both pharmacogenomics and pharmacodynamics, and not all are completely understood for each drug. For each of these steps there are genes involved. Our current genetic testing tests for the commonly known and often implicated genes, but cannot account for all. Additionally, the pharmacokinetics or pharmacogenomics of a drug does not depend solely on one gene.

One phenomenon that cannot be accounted for with genetic testing is phenoconversion. Phenoconversion occurs when individuals, who on pharmacogenomic testing would be identified as genotypically extensive (normal) metabolizers, are actually phenotypically poor metabolizers. The most common causes of phenoconversion are through concomitant use of certain other drugs or co-morbidities such as Human Immunodeficiency Virus (HIV) [13]. For instance, in a patient with depression and breast cancer, a medication like Fluoxetine will inhibit CYP 2D6, transforming an intermediate metabolizer of Tamoxifen into a slow metabolizer. This genotypic-phenotypic dissociation cannot be accounted for in genetic testing.

Another limitation is related to differences between laboratories for testing the same gene. For instance, in checking phenotypes for a specific cytochrome, a lab may test for 5 alleles and another one for 10. The alleles that are not tested for are then presumed to be "normal" metabolizers and that may not be the case.

\section{THE USE OF PHARMACOGENOMICS IN PRACTICE TODAY}

Currently, clinical pharmacogenomics is still in its infancy. Despite our knowledge into the topic, the FDA recommendations for testing remain few. At the present time the only medications that require testing prior to initiation are abacavir and, in certain populations, carbamazepine and oxcarbazepine. Some specialties will test specific genes prior to medication initiation such as tamoxifen, allopurinol, SSRIs, codeine, tramadol, azathioprine, mercaptopurine and certain chemotherapeutic agents. However, this is currently provider dependent. Despite this, direct-to-consumer testing is available and so health care providers require a basic understanding in order to educate and treat as needed.

At present, in the United States, insurance coverage for pharmacogenomic testing is based on the testing required and the indication, and can vary between different insurance providers. To know if their test will be covered, individuals can contact their insurance provider prior to testing.

Most common indications for testing are symptoms suggestive of drug metabolism concerns, medication non-adherence, self-adjustment of dosing or frequency to obtain a clinical benefit, prescription of a medication with a known adverse reaction, family history of intolerance to the drug, or the patient's desire for preemptive testing.

All patients should be educated on the limitations of pharmacogenomics. Pharmacogenomics 
does not completely eliminate the risk of adverse effects or inefficacy when prescribing medication.

\section{CONCLUSION}

Pharmacogenomics is a tool that provides us with information allowing us to move away from the trial and error method of medication prescribing. When used appropriately, this new information allows us to tailor medications and doses to an individual's genetic make-up to facilitate a safe and effective response.

Guidelines for dose adjustments can be found on both the FDA website and the CIPC website.

Farmacogenomica descrie legătura dintre codul genetic şi variabilitatea răspunsului terapeutic sau apariţia efectelor adverse. Se observă o creştere a interesului pentru acest domeniu şi a aplicabilităţii sale. Cunoaşterea interacţiunilor dintre gene şi medicaţie va ajuta clinicianul să aleagă cele mai potrivite medicamente pentru pacient cu evitarea reacţiilor adverse.

Pentru a putea aprofunda acest vast domeniu, clinicienii trebuie să fie familiarizaţi cu principiile de bază ale farmacodinamicii şi farmacocineticii, precum şi cu legătura dintre acestea şi răspunsul terapeutic. Astfel vor putea fi înţelese şi variantele genetice care asociază diferite fenotipuri. Acest articol prezintă aceste concepte şi oferă exemple privind medicamente care se administrează în mod curent în practica clinică. În acest moment ghidurile FDA nu dezvoltă ideea de testare farmacogenomică, deşi există posibilitatea realizării acestor analize. În acest context articolul detaliază cum se interpretează un raport farmacogenomic, precum şi indicaţiile pentru testare şi limitări.

Această informare este un pas înainte pentru medicina personalizată, în speranţa că administrarea terapiei în mod personalizat în functie de terenul genetic al pacientului va duce la o predicţie a tratamentului.

Correspondence to: Razvan Chirila, MD, 4500 San Pablo Road South, 32224, Jacksonville, Florida, USA

Phone: +19049532824

Fax: +19049532848

E-mail: Chirila.Razvan@mayo.edu

Conflicts of interest disclosure: The authors declare that there are not conflicts of interest.

Acknowledgments: None.

\section{REFERENCES}

1. ORRICO K., Basic concepts in genetics and pharmacogenomics for pharmacists, Drug Target Insights, 2019, doi: 10.1177/ 1177392819886875.

2. 2019, Table of pharmocaogenomic Biomarkers in Drug Labelling. FDA. Viewed: 12/11/2019, https://www.fda.gov/Drugs/Science Research/ucm572698.htm.

3. MAREZ D., LEGRAND M., SABBAGH N., LO GUIDICE J.M., SPIRE C., LAFITTE J.J. et al., Polymorphism of the cytochrome P450 CYP2D6 in a European population: Characterization of 48 mutations of 53 alleles, their frequencies and evolution, Pharmacogenetics, 1997, 7(3): 193.

4. KELLY L., RIEDER M., VAN DEN ANKER J., MALKIN B., ROSS C., NEELY M.N. et al., More codeine fatalities after tonsillectomy in North American children, Pediatrics, 2012, 129(5).

5. GOETZ M., SANGKUHL K., GUCHELAAR H.J., SCHWAB M., PROVINCE M., WHIRL-CARRILlO M. et al., Clinical Pharmacogenetics Implementation Consortium (CPIC) guideline for CYP2D6 and tamoxifen therapy, Clin. Pharmacol. Ther., 2018, 103(5):770-777.

6. RAY S., Clopidogrel resistance: The way forward, Indian heart journal, 2014, 66(5):530-534.

7. RUSH A.J., FAVA M., WISNIEWSKI S.R., LAVORI P.W., TRIVEDI M.H., SACKEIM H.A. et al., Sequenced Treatment Alternatives to Relieve Depression. Control clin trials, 2004, 25(1):119-142. 
8. EVANS W.E., HON Y.Y., BOMGAARS L., COUTRE S., HOLDSWORTH M., JANCO R. et al., Preponderance of thiopurine S-methyltransferase deficiency and heterozygosity among patients intolerant to mercaptopurine or azathioprine, Journal of Clinical Oncology, 2001, 19(8):2293-2301.

9. RELling M. et al., Clinical Pharmacogenetics Implementation Consortium Guidelines for Thiopurine Methyltransferase Genotype and Thiopurine Dosing: 2018 update, CIPC update, 2018.

10. BRUNHAM L. et al., Role of genetics in the prediction of statin-associated muscle symptoms and optimization of statin use and adherence, Cardiovasc. Res., 2018, 114(8):1073.

11. TARAVES L. et al., Genotype-guided warfarin therapy: The current status, Pharmacogenomics, 2018, 19(7):667-685.

12. 2019, Direct-To-Consumer Testing. FDA. Viewed: 12/25/2019 https://www.fda.gov/medical-devices/vitro-diagnostics/directconsumer-tests\#list

13. SHAH R., SMITH R., Addressing phenoconversion: The Achillies' heel of personalised medicine, Brit. J. Clin. Pharmacol., $2015,79(2): 222-240$.

Received January $28^{\text {th }} 2020$ 